Article

\title{
Over Exploitation of Groundwater in the Centre of Amman Zarqa Basin-Jordan: Evaluation of Well Data and GRACE Satellite Observations
}

\section{Sana'a Al-Zyoud ${ }^{1, \dagger, *}$, Wolfram Rühaak ${ }^{2,3, \dagger}$, Ehsan Forootan ${ }^{4, \dagger}$ and Ingo Sass ${ }^{2,3}$}

1 Applied Earth and Environmental Sciences Department, Institute of Earth and Environmental Sciences, Al al-Bayt University, P.O. Box 130040, Mafraq 25113, Jordan

2 Darmstadt Graduate School of Excellence Energy Science and Engineering, Technische Universität Darmstadt, Jovanka-Bontschits-Straße 2, Darmstadt D-64287, Germany; E-Mails: ruehaak@geo.tu-darmstadt.de (W.R.); sass@geo.tu-darmstadt.de (I.S.)

3 Department of Geothermal Science and Technology, Technische Universität Darmstadt, Schnittspahnstr. 9, Darmstadt D-64287, Germany

4 Institute of Geodesy and Geoinformation, Bonn University, Nussallee 17, Bonn 53115, Germany; E-Mail: forootan@geod.uni-bonn.de

$\dagger$ These authors contributed equally to this work.

* Author to whom correspondence should be addressed; E-Mail: alzyoud@aabu.edu.jo; Tel.: +962-2-6297000 (ext. 2834).

Academic Editor: John A. Luczaj

Received: 2 July 2015 / Accepted: 2 November 2015 /Published: 6 November 2015

Abstract: Jordan faces a sincere water crisis. Groundwater is the major water resource in Jordan and most of the ground water systems are already exploited beyond their estimated safe yield. The Amman Zarqa Basin is one of the most important groundwater systems in Jordan, which supplies the three largest cities in Jordan with drinking and irrigation water. Based on new data the groundwater drawdown in the Amman Zarqa Basin is studied. This basin is the most used drainage area in Jordan. Groundwater drawdown in eight central representative monitoring wells is outlined. Based on almost continuous data for the last 15 years (2000-2015) an average drawdown for the whole basin in the order of $1.1 \mathrm{~m} \cdot \mathrm{a}^{-1}$ is calculated. This result is in accordance with results of previous studies in other areas in Jordan and shows that, until now, no sustainable water management is applied. Groundwater management in such a basin presents a challenge for water managers and 
experts. The applicability of satellite data for estimating large-scale groundwater over exploitation, such as gravity products of the Gravity Recovery and Climate Experiment (GRACE) mission, along with supplementary data, is discussed. Although the size of the basin is below the minimum resolution of GRACE, the data generally support the measured drawdown.

Keywords: groundwater drawdown; Amman Zarqa Basin; Jordan; GRACE

\section{Introduction}

Aim of this study is to present new data about the groundwater depletion in the Amman Zarqa Basin in Jordan during 2000-2015. In addition to scattered and relatively sparse well data observations, GRACE satellite data are evaluated to find out if a general groundwater loss is reflected in these gravity measurements.

\subsection{Study Area}

The Jordanian part of Amman Zarqa Basin (Figure 1) covers an area of $3739 \mathrm{~km}^{2}$ compared to $310 \mathrm{~km}^{2}$ in Syria [1]. This basin represents the transitional area between western hills and eastern desert. The climatological conditions change from humid to arid leading to different land use patterns. The western hilly areas are relatively densely populated, whereas the southeast areas are deserts and almost without population. More than $60 \%$ of the population of Jordan [2] is located inside the basin. In the areas of upper Zarqa, Baqa'a, Dhulail, and Jerash the groundwater is mainly used for irrigation. According to [3] different agriculture products exist (cereals, vegetables, fruit trees). According to [4] in $201022 \%$ of the land cover are urban, mixed rain-fed areas sum up to $37 \%$ and irrigated areas sum up to $2.4 \%$.

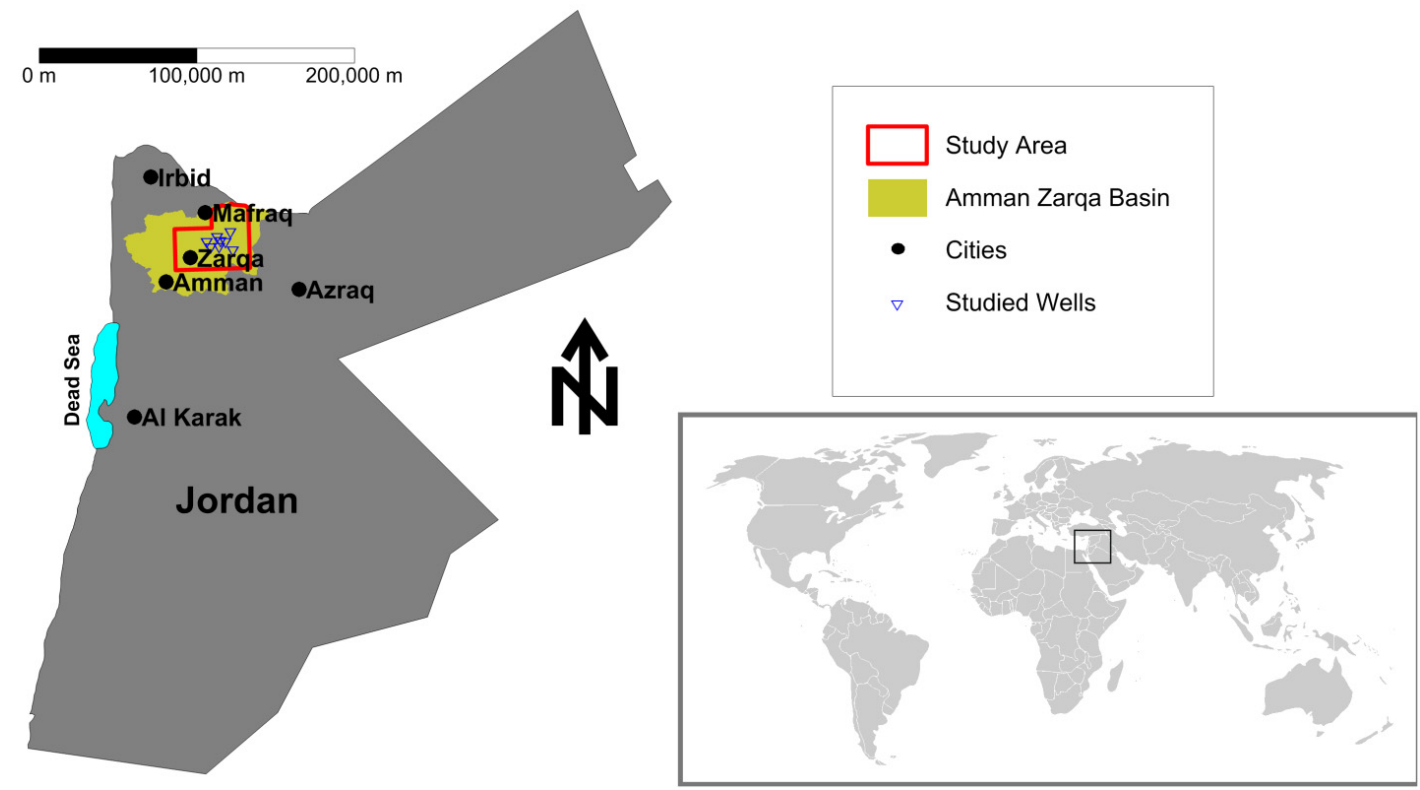

Figure 1. A simplified map of Jordan showing the location of the study area, the Amman Zarqua Basin, and of the studied wells. 
The three main aquifers in the Amman Zarqa Basin are formed by (1) a basaltic eruption at the top, (2) a limestone aquifer in the middle, and (3) a sandstone aquifer at the bottom. The upper two aquifers are hydraulically connected. They are underlain by a 20-35 m thick marl formation. The limestone formation, called Amman-Wadi As Sir (B2/A7), is the most important aquifer in the basin. It has a large and continuous extent together with a high hydraulic conductivity. It is considered as the main source of fresh water for domestic, as well as irrigated agricultural, uses. The Amman Zarqa Basin is underlain by the sandstones of the Kurnub-Ram Formations, which form a deeper aquifer system. The Ajlun marl aquitard separates the sandstones from the Basalt Aquifer Complex [5].

The uppermost basaltic aquifer which is formed by highly vesicular lava flows has, based on pumping tests, transmissivity values in the range from $5.0 \times 10^{-5}$ to $5.4 \times 10^{-1} \mathrm{~m}^{2} \cdot \mathrm{s}^{-1}$, the average is about $8 \times 10^{-2} \mathrm{~m}^{2} \cdot \mathrm{s}^{-1}$, corresponding to a mean hydraulic conductivity of $2.3 \times 10^{-4} \mathrm{~m} \cdot \mathrm{s}^{-1}$. The transmissivity of the limestone aquifer (B2/A7) varies between $5.4 \times 10^{-5}$ and $2.5 \times 10^{-2} \mathrm{~m}^{2} \cdot \mathrm{s}^{-1}$, the average is about $5 \times 10^{-3} \mathrm{~m}^{2} \cdot \mathrm{s}^{-1}$, corresponding to a mean hydraulic conductivity of $8.1 \times 10^{-5} \mathrm{~m}^{2} \cdot \mathrm{s}^{-1}$ [6].

Mean discharge rate values in different areas of the basin are between 1 and $40 \mathrm{~m}^{3} \cdot \mathrm{h}^{-1}$ corresponding with transmissivity values of shallow basalt aquifer between $3.47 \times 10^{-4}$ and $1.50 \times 10^{-2} \mathrm{~m}^{2} \cdot \mathrm{s}^{-1}$.

The basalt sequence has a thickness of $100 \mathrm{~m}-300 \mathrm{~m}$. Transmissivity values are estimated at around $1.0 \times 10^{-2} \mathrm{~m}^{2} \cdot \mathrm{s}^{-1}$ with corresponding mean hydraulic conductivity of $2 \times 10^{-4}$ to $6 \times 10^{-4} \mathrm{~m} \cdot \mathrm{s}^{-1}$ [5].

\subsection{Water Availability}

Water availability is an important factor controlling human's wealth and prosperity, especially in arid and semi-arid regions [7]. Jordan has a water scarcity probably more serious than other countries in the Middle East [8,9]. This shortage is due to many reasons, such as low rainfall of $100-150 \mathrm{~mm} \cdot \mathrm{a}^{-1}[9,10]$ with an annual rainfall decrease at an average rate of $1.2 \mathrm{~mm}$ [9], uneven water distribution, high water volume losses due to evaporation, and an increasing demand on drinking and agricultural water due to population growth [11]. Surface water resources are very limited in Jordan; therefore, groundwater is the main water resource [6]. As a result, extensive groundwater pumping is taking place in the Jordanian groundwater systems with the use of public and private wells. Rimawi and Al Ansari [12] found that groundwater salinity in the upper aquifer complex in the north-eastern part of the Al Mafraq area (Figure 1) has increased in the last decades. This is due to intensive exploitation of groundwater for irrigation purposes. Salameh [13] showed the lowering trend for some selected wells within the Jordanian area. He concluded that the major Jordan basins may be beyond restoration.

El-Naqa et al. [14] found that Azraq Basin (the southeastern neighbor basin of Amman Zarqa Basin) is suffering from groundwater drawdown due to extensive overexploitation. Bajjali et al. [15] found that, in the central part of Amman Zarqa Basin, the groundwater level is declining approximately one meter per year.

Ta'any et al. [1] applied geostatistics to analyze the spatial and temporal variations of groundwater level fluctuations in 33 wells scattered in the Amman Zarqa Basin. They have been analyzed for the period of 2001-2005. The annual drawdown in wells of [1] is ranging from 0.47 to $1.68 \mathrm{~m}$. Five wells of this study are common with the work of Ta'any et al. [1]. 
New groundwater level data from eight wells in the Amman Zarqa Basin have been studied. The study area is about $28 \mathrm{~km}$ NE of Zarqa city (Figure 1), the second largest city in Jordan. Many industrial infrastructures are located in the basin, such as the Jordanian Free Zone Areas, the refinery of Jordan, and the Al Hussain power station; the main power station in Jordan. It is the largest industrial city in Jordan. It is considered the most polluted area in Jordan.

In general, the water level is declining in almost all wells in the basin. The Ministry of Water and Irrigation [16] reported that the declines in water level of the limestone aquifer (B2/A7) range between $0.67 \mathrm{~m}$ and $2.0 \mathrm{~m}$ per year. Al Mahamid [6] predicted that the maximum accumulative drawdown will reach more than $70 \mathrm{~m}$ in the year 2025 . He forecasted that some wells between Al Khalidiyya and Umm Al Jimal-located in the middle basin area-will become completely dry. Margane et al. [17] reported, too, that the exploitation of the limestone aquifer (A7/B2) has increased over the past decade, so that water levels are rapidly declining in about $2 \mathrm{~m} \cdot \mathrm{a}^{-1}$.

The following recent data show that a continuous water level decline is happening in the upper basaltic aquifer of Amman Zarqa Basin.

Remote sensing is a powerful technique for studying groundwater at regional scales [18]. In this study the result of the field data is compared with GRACE satellite data.

\section{Methods and Data}

\subsection{Well Data}

The wells discussed in the following are located in the northeastern Jordanian desert in the center of the Amman Zarqa Basin (Figure 1). Their records refer to the water level of the upper aquifer in Amman Zarqa Basin. As this aquifer is an unconfined aquifer, a dropping water level, therefore, reflects an actual decrease in reserves.

Eight monitoring wells which have complete water level records (Ministry of Water and Irrigation MWI [19]) over the last fifteen years (Table 1) were selected in the area (Figures 1 and 2).

The wells are located in the central part of the basin under the largest unprotected industrial zone in Jordan. The data were gathered for the last 15 years (2000-2015) and give detailed information about the condition and operation of the wells.

Table 1. Groundwater drawdown in the studied wells.

\begin{tabular}{ccccc}
\hline Well Name & $\begin{array}{c}\text { Total Cumulative } \\
\text { Drawdown (m) }\end{array}$ & $\begin{array}{c}\text { Well Observation } \\
\text { Period }\end{array}$ & $\begin{array}{c}\text { Total Time } \\
\text { (a) }\end{array}$ & $\begin{array}{c}\text { Mean Annual Drawdown } \\
\text { from 2000 Till 2015 (m) }\end{array}$ \\
\hline AL 1043 & 31.11 & $01 / 2000-03 / 2015$ & 15.17 & 2.05 \\
AL 1926 & 28.09 & $01 / 2000-02 / 2015$ & 15.10 & 1.86 \\
AL 2698 & 18.25 & $01 / 2000-02 / 2015$ & 15.10 & 1.21 \\
AL 3384 & 14.28 & $01 / 2000-02 / 2015$ & 15.10 & 0.95 \\
AL 1022 & 10.98 & $03 / 2000-01 / 2014$ & 13.83 & 0.79 \\
AL 3387 & 10.75 & $06 / 2001-03 / 2015$ & 13.80 & 0.78 \\
AL 1041 & 59.79 & $01 / 2000-01 / 2013$ & 13.00 & 4.60 \\
AL 1040 & 11.33 & $01 / 2000-05 / 2013$ & 13.30 & 0.85 \\
\hline
\end{tabular}




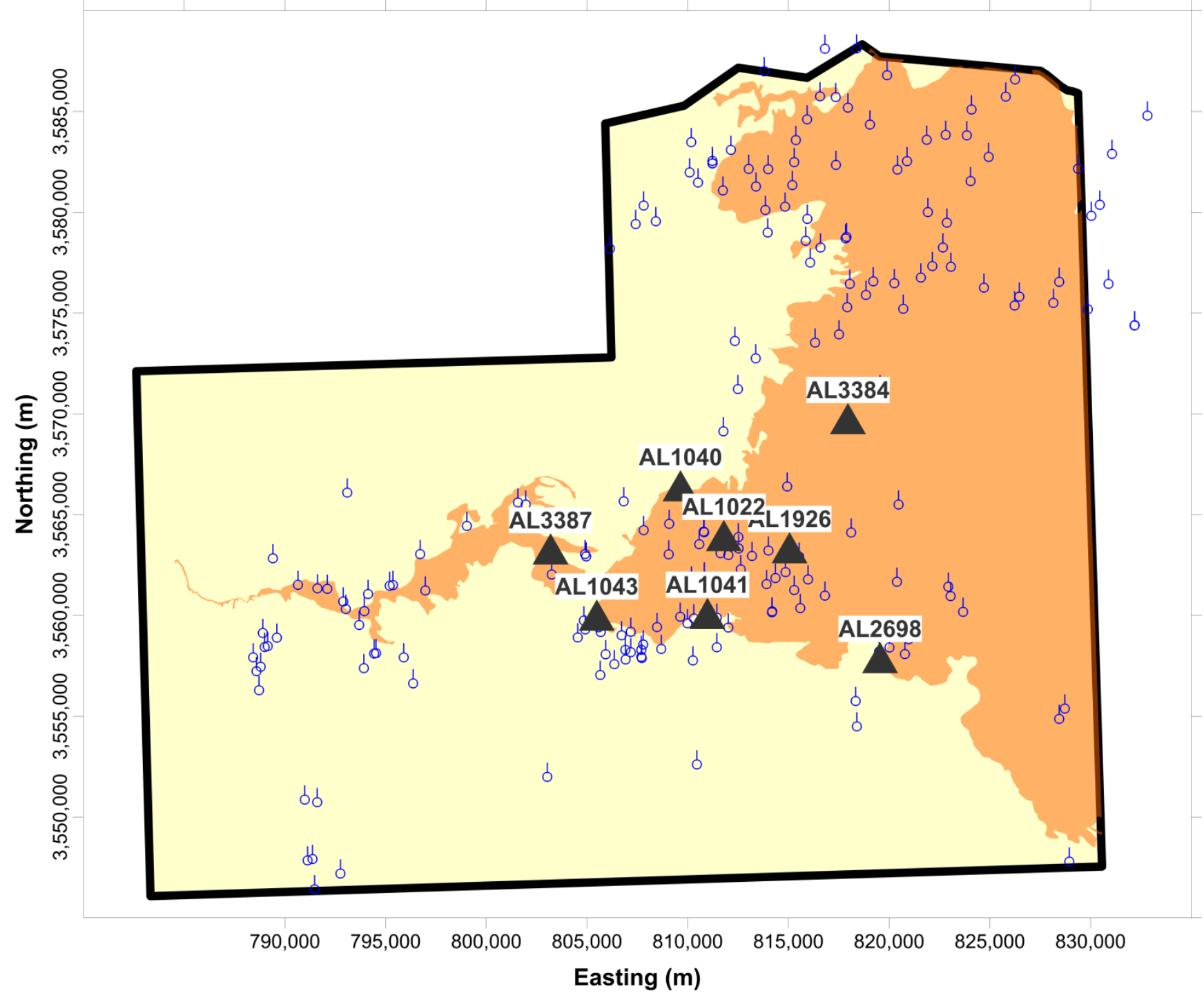

Figure 2. A simplified geological map of the upper aquifer of the Jordanian Harrat basalt showing the long-term monitoring wells discussed in this study, together with all other available wells (coordinates UTM 36 North).

\subsection{Remote Sensing}

Since March 2002, the Gravity Recovery and Climate Experiment (GRACE) is routinely providing satellite-based estimates of changes in total water storage (TWS, known as a vertical integration of water changes due to vegetation changes, surface water, soil moisture, and groundwater changes) within the Earth's system. Using GRACE data it is possible to quantify amounts of groundwater usage [20]. GRACE monthly gravity products have been recently used in few studies to explore hydrological patterns within the Middle East. For instance, Longuevergne et al. [21] and Voss et al. [22] showed a pattern of water storage loss over a large area of Northwest Asia, including the Tigris River Basin (Iraq and Syria), extending to Northwestern Iran, including the Urmia Basin. Forootan et al. [23] showed that the extension of groundwater changes can be estimated using GRACE and complementary products within a joint inversion technique. The proposed method is adopted in this study to estimate the large-scale extension of groundwater drawdown over the study area. 
Total water storage (TWS) data within a rectangular box (between $28^{\circ}$ to $34^{\circ} \mathrm{N}$ and $34^{\circ}$ to $40^{\circ} \mathrm{E}$ ) that includes Jordan, is extracted from each monthly GRACE-TWS map, which was computed using the Release 5 products of the Center for Space Research (CSR, University of Texas, Austin), over January 2003 to July 2014, following the approach in [24]. Degree one and two coefficients have been replaced by the satellite laser ranging products following the advice given by the GRACE team $[25,26]$. Correlated errors in GRACE-derived TWS products were reduced using the de-correlation filter of DDK3 [27]. The signal damping due to the application of the DDK3 filter was accounted by computing a single scale factor ( $4 / 3$ in this study) that is derived as the ratio of the spatial average of a homogenous TWS field (filled by $1 \mathrm{~mm}$ within the box area) to the spatial average of the same field after application of the DDK 3 filter. Figure 3 shows the linear rate of TWS changes over January 2003 to July 2014. Please note that the scale of TWS changes is $1 \mathrm{~mm}$ in a $100 \mathrm{~km} \times 100 \mathrm{~km}$ area; thus, the vertical changes cannot be directly compared to the estimated groundwater changes from in situ wells.

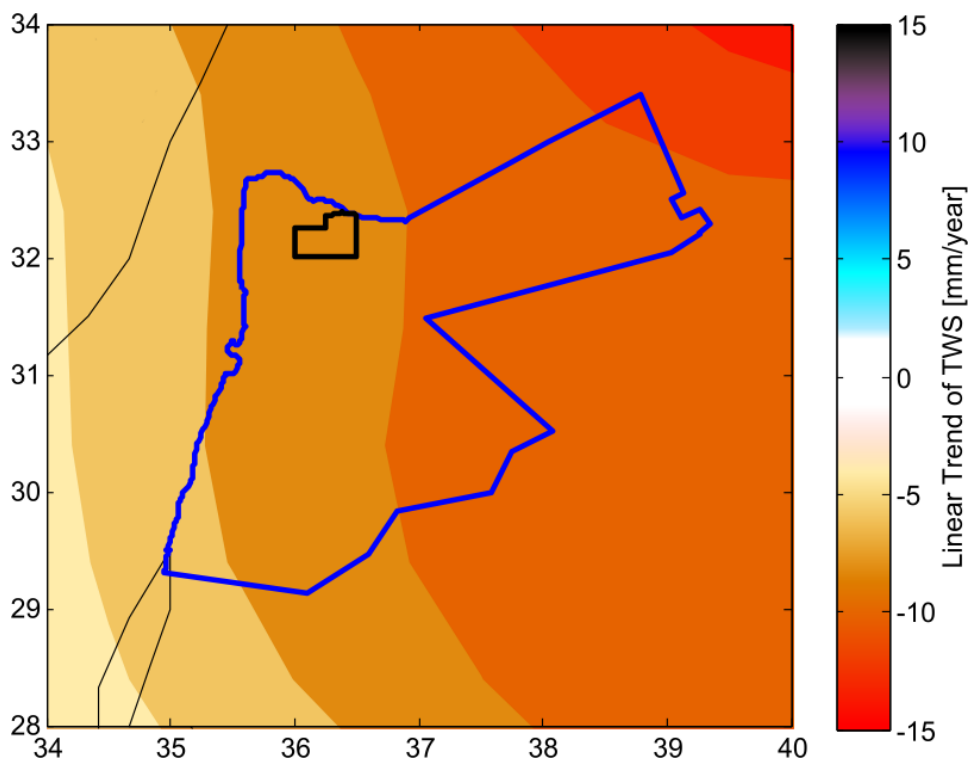

Figure 3. Linear trend over January 2003 to July 2014 derived from GRACE-TWS maps (geographic coordinates).

Over the same period, gridded altimetry data (representing surface water storage changes) derived from the Environmental Research Division's Data Access Program, while the terrestrial water storage changes, including the summation of canopy and soil moisture changes, were derived from the output of the Global Land Data Assimilation System (GLDAS [28]). The dominant independent patterns of altimetry (including the Dead Sea and the Mediterranean Sea) and GLDAS were estimated using the independent component analysis technique [29] and the spatial patterns were introduced as known (base-functions) to separate GRACE-TWS maps in a least squares adjustment (LSA) procedure (similar to [23]). This procedure makes the best use of all available datasets in a LSA framework and reduces the leakage impact due to the implementation of mandatory filtering. Once the base-functions (from altimetry and GLDAS) were adjusted to GRACE-TWS observation, they were used to remove the contribution of surface and terrestrial water storage changes from TWS time-series and compute groundwater changes. The inversion step adopts temporal variability of GLDAS to what is likely reflected in GRACE-TWS. Therefore, it accounts for the resolution mismatch between GLDAS and 
GRACE data. It should be mentioned here that the steric level changes in the Mediterranean Sea was accounted for using sea surface temperature (SST) data as in [22], therefore, the steric changes due to salinity changes was neglected. No SST was found over the Dead Sea; thus, the estimated volume changes were considered as mass variability.

Groundwater signal estimated from GRACE observations might be contaminated with signals originating from regions outside the region of interest, or the signal of the target area might be moved out as a result of filtering that is used to post process GRACE estimations. Both effects are known as the spatial leakage problem in GRACE related studies. However, various studies indicate that GRACE observations can be used over small regions when care is taken of this leakage problem (see e.g., [30]). In this study, a new methodology was applied, which allows one to mitigate the possible effect of leakage by inversion. This method has already been used to study water storage changes over the Middle East and the results have been evaluated with groundwater observations [23].

\section{Study Results}

\subsection{Well Data}

The groundwater level change shown in Figure 4 and Table 1 extends from different dates where the pumping has started up to early of 2015. The average drawdown was calculated to be $1.64 \mathrm{~m} \cdot \mathrm{a}^{-1}$ in the last 15 years.

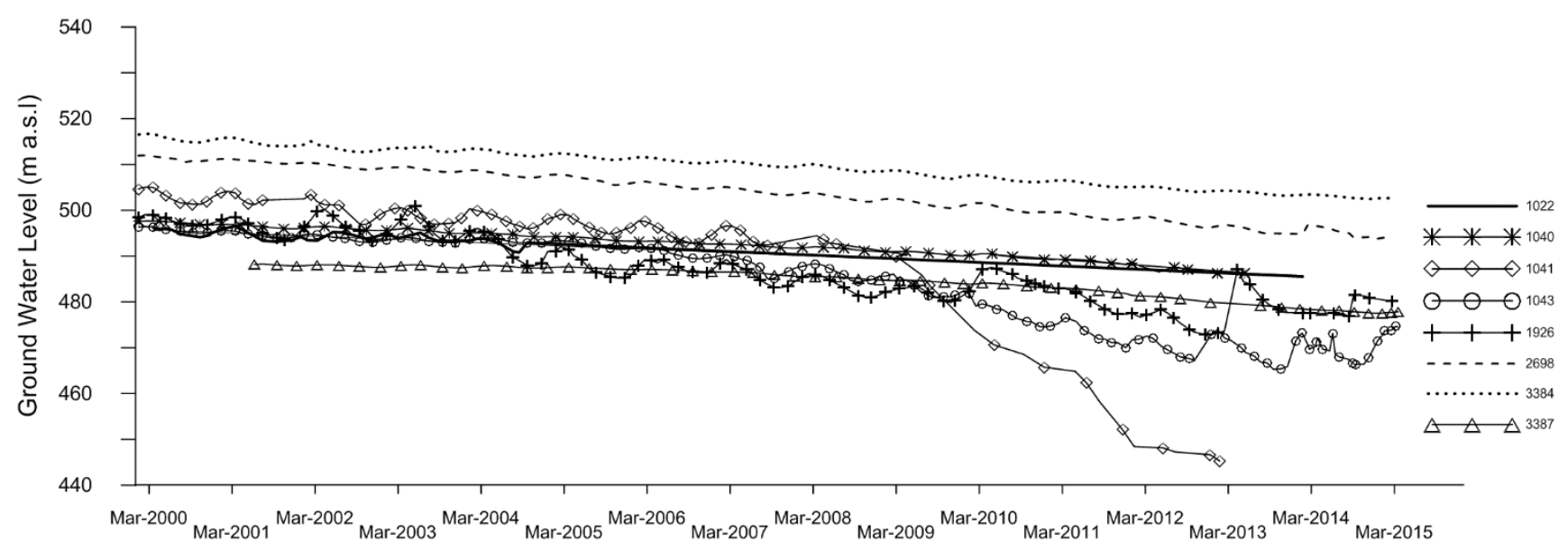

Figure 4. Groundwater drawdown in all studied wells from January 2000 until April 2015.

The report of the Ministry of Water and Irrigation [16] shows that since the early 1960s groundwater levels are declining in this basin. Each well shown in Figure 4 shows a clear water level declination.

According to [6] recharge from rainfall is approximately $45 \times 10^{6} \mathrm{~m}^{3} \cdot \mathrm{a}^{-1}$ and approximately $62 \times 10^{6} \mathrm{~m}^{3} \cdot \mathrm{a}^{-1}$ from lateral subsurface inflow. Accordingly, the outflow is in the order of $66 \times 10^{6} \mathrm{~m}^{3} \cdot \mathrm{a}^{-1}$ into Azraq Basin (neighboring in the south-east [31]) and $3.4 \times 10^{6} \mathrm{~m}^{3} \cdot \mathrm{a}^{-1}$ into Yarmouk Basins (neighboring to the north [31]). The leakage into the lower aquifer is about $12 \times 10^{6} \mathrm{~m}^{3} \cdot \mathrm{a}^{-1}$. In Mafraq and the Dhuleil- Hallabat area in the central Amman Zarqa Basin it was found that the groundwater is transferred laterally and vertically from the basalts to the lower Amman Wadi Sir limestone [32]. In addition there is an amount of $27 \times 10^{6} \mathrm{~m}^{3} \cdot \mathrm{a}^{-1}$ underflow towards the Zarqa River. 
The average drawdown trend observed at the studied wells with $1.64 \mathrm{~m} \cdot \mathrm{a}^{-1}$ for 15 years should not be considered as the representative trend for the Amman Zarqa Basin, since they are concentrated on the central basin. Furthermore, the hydrogeological settings of the Amman Zarqa Basin are complex due to numerous large fault systems.

However, the presented results are in good agreement with previous data $[1,5,6,13-17,33]$. In average all these studies stated an annual groundwater level drawdown in the order of $0.65 \mathrm{~m}$ to $2.0 \mathrm{~m}$.

\subsection{Remote Sensing}

Figure 5a shows the linear trend from GRACE adjusted terrestrial water storage (including soil moisture and vegetation changes) during January 2003 to July 2014. The results indicate a decrease in soil moisture (approximately $-15 \mathrm{~mm}$ per year in water column) over the country, which is dominated mainly over the northeastern and western regions. A linear trend of groundwater is shown in Figure 5b), which indicates a decline of groundwater at the rate of up to approximately $-10 \mathrm{~mm}$ per year in the water column concentrated over the study area. This value is equivalent with approximately $160 \mathrm{~mm}$ per year in groundwater change concentrated over the model area.

It should be mentioned here that GRACE has usually been used for basins larger than $100,000 \mathrm{~km}^{2}$ [34]; thus, for basins such as the one studied here, estimations of terrestrial water storage might include a significant level of uncertainty. However, the results in Figure 5 are consistent with those of previous studies [23].

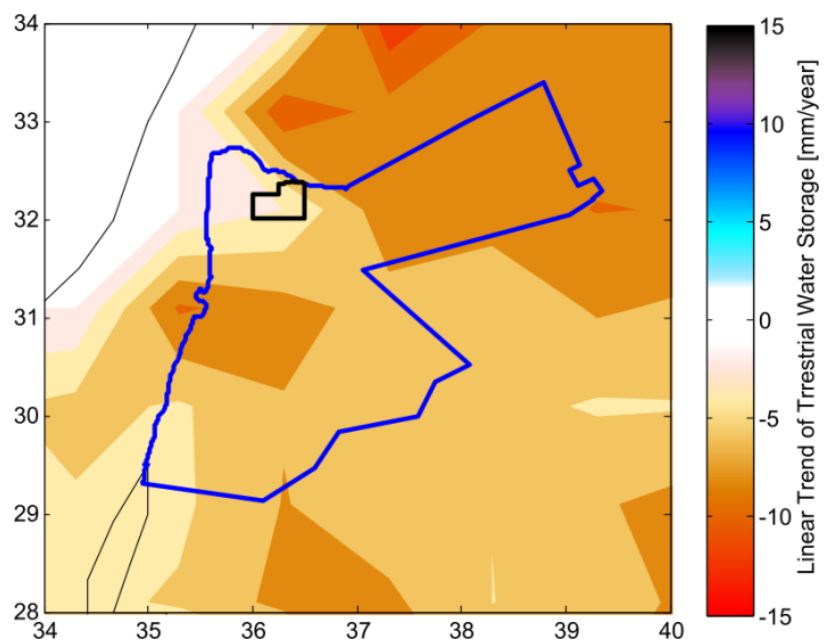

(a)

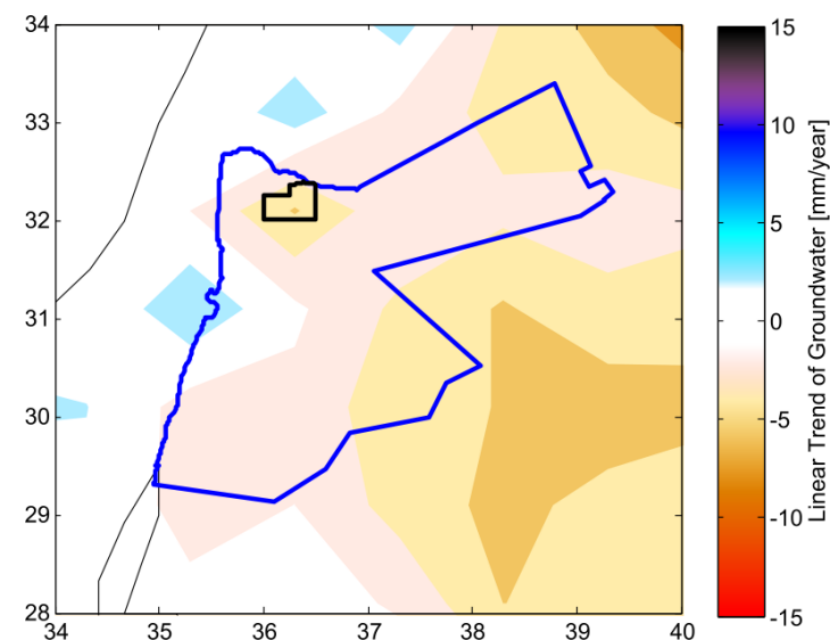

(b)

Figure 5. Linear trend over January 2003 to July 2014 derived from GRACE observations and complimentary data (compare with Figure 3). (a) From GRACE-adjusted terrestrial water storage products (showing the variability in soil moisture and biomass); and (b) side from groundwater storage maps (geographic coordinates).

\section{Discussion}

The groundwater resources in the Amman Zarqa Basin in Jordan are overused. The basin safe yield is 87.5 million $\cdot \mathrm{m}^{3}$, while the actual pumping is 156.3 million $\mathrm{m}^{3}$, resulting in a groundwater depletion 
of 68.8 million $\cdot \mathrm{m}^{3}$ by the end of 2013 [35]. Numerous wells in the basin document for the evaluated 15 years an average annual groundwater drawdown of $1.64 \mathrm{~m} \cdot \mathrm{a}^{-1}$.

In addition to the over-usage of the groundwater, rainfall has notably declined since 1995 [9]. However, as no precise data of the total pumping exist and recharge rates are estimated [3], no valid hydrological water balance can be calculated.

Although the basin's size is beyond the resolution of the GRACE data, which inhibits detailed predictions, these satellite data also indicate severe groundwater depletion.

Another indication for groundwater depletion, which can be detected by satellites, is subsidence. InSAR or GPS data (e.g., [36,37]) could be evaluated, even if the occurring subsidence may be in the order of the detection limit.

\section{Conclusions}

Decision-makers should finally recognize the serious groundwater overexploitation status in this area, which has not changed since the last data were published. The groundwater table is still slowly depleting. The urge to find more appropriate solutions for the groundwater management in Jordan is seriously needed.

The major Jordan basins may have become beyond restoration. In any case groundwater extraction should be limited to yield the remaining groundwater resources of the basin.

Measures have to be taken that the access to enough water resources is guaranteed for future generations. To preserve the groundwater resource for future generations all reasons for the groundwater depletion have to be studied carefully. The urgency to implement the necessary measures is, again, proven by this study which should be understood as a part within a framework of national and international investigations.

\section{Acknowledgments}

This work is partly supported by the Alliance of Science Organizations in Germany (DFG) in the framework of the Excellence Initiative, Darmstadt Graduate School of Excellence Energy Science and Engineering (GSC 1070).

\section{Author Contributions}

The authors have contributed in several ways. Ingo Sass initiated this study, Sana'a Al-Zyoud evaluated the well data and the literature about the regional hydrogeology, Ehsan Forootan evaluated the GRACE data set, Wolfram Rühaak initiated the combination of field data with satellite data and compiled the paper. All authors contributed to the text.

\section{Conflicts of Interest}

The authors declare no conflict of interest. 


\section{References}

1. Ta'any, R.; Tahboub, A.; Saffarini, G. Geostatistical analysis of spatiotemporal variability of groundwater level fluctuations in Amman Zarqa basin, Jordan: A case study. Environ. Geol. 2009, $57,525-535$.

2. DOS Jordan Department of Statistics 2010. Available online: http://www.dos.gov.jo/sdb_pop/ sdb_pop_e/ehsaat/alsokan/2010/2-2.pdf (accessed on 3 November 2015).

3. Al-Abed, N.; Al-Sharif, M. Hydrological modeling of Zarqa River Basin-Jordan using the hydrological simulation program-FORTRAN (HSPF) model. Water Resour. Manag. 2008, 22, 1203-1220.

4. Al-Bakri, J.T.; Salahat, M.; Suleiman, A.; Suifan, M.; Hamdan, M.R.; Khresat, S.; Kandakji, T. Impact of climate and land use changes on water and food security in Jordan: Implications for transcending "the tragedy of the commons". Sustainability 2013, 5, 724-748.

5. UN-ESCWA and BGR (United Nations Economic and Social Commission for Western Asia; Bundesanstalt für Geowissenschaften und Rohstoffe); Inventory of Shared Water Resources in Western Asia: Beirut, Lebanon, 2013.

6. Al Mahamid, J. Integration of water resources of the upper aquifer in Amman-Zarqa basin based on mathematical modeling and GIS, Jordan, Freiberg Online Geology, Germany, 2005, Available online: http://citeseerx.ist.psu.edu/viewdoc/download?doi=10.1.1.225.991\&rep=rep1\&type=pdf (accessed on 6 August 2015).

7. Sidiropoulos, P.; Mylopoulos, N.; Loukas, A. Optimal management of an overexploited aquifer under climate change: The Lake Karla case. J. Water Resour. Manag. 2013, 27, 1635-1649.

8. Al-Weshah, R. Jordan's water resources: Technical perspective. Water Int. 1992, 17, 124-132.

9. Rahman, K.S.M.; Gorelick, P.J.; Dennedy-Frank, J.; Yoon, B. Rajaratnam, declining rainfall and regional variability changes in Jordan. Water Resour. Res. 2015, 51, doi:10.1002/2015WR017153.

10. Jordan Meteorological Department. Department Data Base; JMD: Amman, Jordan, 2015.

11. Al-Kharabsheh, A.; Al-Mahamid, J. Optimizing pumping rates of Hallabat-Khalidiya Wellfield using finite-difference model: A case study for evaluating over pumped aquifers in arid areas (Jordan). J. Arid Environ. 2002, 52, 259-267.

12. Rimawi, O.; Al-Ansari, N. Groundwater degradation in the northeastern part of Mafraq area, Jordan. In Freshwater Contamination, Proceedings of Rabat Symposium S4; April-May 1997; IAHS Publ.: Oxfordshire, UK, pp. 235-243.

13. Salameh, E. Over-exploitation of groundwater resources and their environmental and socio-economic implications: The case of Jordan. Water Int. 2008, 33, 55-68.

14. El-Naqa, A.; Al-Momani, M.; Kilani, S.; Hammouri, N. Groundwater deterioration of shallow groundwater aquifers due to overexploitation in northeast Jordan. Clean Soil Air Water 2007, 35, 156-166.

15. Bajjali, W.; Al-Hadidi, K.; Ismail, M. Water quality and geochemistry evaluation of groundwater upstream and downstream of the Khirbet Al-Samra wastewater treatment plant/Jordan. J. Appl. Water Sci. 2015, doi:10.1007/s13201-014-0263-x.

16. Outline Hydrogeology of the Amman-Zarqa Basin, Report: Water Resources Policy Support; MWI Ministry of Water and Irrigation: Amman, Jordan, 2000. 
17. Margane, A.; Hobler, M.; al Momani, M.; Subah, A. Contributions to the Hydrogeology of Northern and Central Jordan-Geologisches Jahrbuch C 68; Schweizerbart Science Publishers: Stuttgart, Germany, 2002; p. 52.

18. Becker, M.W. Potential for satellite remote sensing of ground water. Ground Water 2006, 44, 306-318.

19. MWI Files and Personal Communications; MWI Ministry of Water and Irrigation: Amman, Jordan, 2010.

20. Richey, A.S.; Thomas, B.F.; Lo, M.-H.; Reager, J.T.; Famiglietti, J.S.; Voss, K.; Swenson, S.; Rodell, M. Quantifying renewable groundwater stress with GRACE. Water Resour. Res. 2015, 51, 5217-5238.

21. Longuevergne, L.; Wilson, C.R.; Scanlon, B.R.; Crétaux, J.-F. GRACE water storage estimates for the Middle East and other regions with significant reservoir and lake storage. Hydrol. Earth Syst. Sci. Discuss. 2012, 9, 11131-11159.

22. Voss, K.A.; Famiglietti, J.S.; Lo, M.-H.; de Linage, C.; Rodell, M.; Swenson, S.C. Groundwater depletion in the Middle East from GRACE with implications for transboundary water management in the Tigris-Euphrates-Western Iran region. Water Resour. Res. 2013, 49, doi:10.1002/wrcr.20078.

23. Forootan, E.; Rietbroek, R.; Kusche, J.; Sharifi, M.A.; Awange, J.; Schmidt, M.; Omondi, P.; Famiglietti, J. Separation of large scale water storage patterns over Iran using GRACE, altimetry and hydrological data. Remote Sens. Environ. 2014, 140, 580-595.

24. Wahr, J.; Molenaar, M.; Bryan, F. Time variability of the Earth's gravity field: Hydrological and oceanic effects and their possible detection using GRACE. J. Geophys. Res. 1998, 103, 30205-30229.

25. Jet Propulsion Laboratory, Geocenter-Degree 1. Available online: http://grace.jpl.nasa.gov/data/ get-data/geocenter/ (accessed on 26 September 2015).

26. Jet Propulsion Laboratory, Spherical Harmonic coefficients of Degree 2. Available online: http://grace.jpl.nasa.gov/data/get-data/oblateness/ (accessed on 26 September 2015).

27. Kusche, J.; Schmidt, R.; Petrovic, S.; Rietbroek, R. Decorrelated GRACE time-variable gravity solutions by GFZ, and their validation using a hydrological model. J. Geod. 2009, 83, 903-913.

28. Rodell, M.; Houser, P.R.; Jambor, U.; Gottschalck, J.; Mitchell, K.; Meng, K.; Arsenault, K.; Cosgrove, B.; Radakovich, J.; Bosilovich, M.; et al. The global land data assimilation system. Bull. Am. Meteorol. Soc. 2004, 85, 381-394.

29. Forootan, E.; Kusche, J. Separation of global time-variable gravity signals into maximally independent components. J. Geod. 2012, 86, 477-497.

30. Longuevergne, L.; Scanlon, B.R.; Wilson, C.R. GRACE hydrological estimates for small basins: Evaluating processing approaches on the High Plains Aquifer, USA. Water Resour. Res. 2010, 46, doi:10.1029/2009WR008564.

31. Goode, D.J.; Senior, L.A.; Subah, A.; Jaber, A. Groundwater-Level Trends and Forecasts, and Salinity Trends, in the Azraq, Dead Sea, Hammad, Jordan Side Valleys, Yarmouk, and Zarqa Groundwater Basins, Jordan; Open-File Report 2013-1061; U.S. Department of the Interior: Washington, DC, USA; U.S. Geological Survey: Reston, VA, USA, 2013.

32. Abu Sharar, R. Water chemistry of the Dhuleil aquifer (Jordan) as influenced by long term pumping. J. Hydrol. 1993, 149, 49-66. 
33. Bajjali, W.; Al-Hadidi, K. Recharge origin, overexploitation, and sustainability of water resources in an arid area from the Azraq basin, Jordan: Case study. Hydrol. Res. 2006, 37, 277-292.

34. Swenson, S.; Wahr, J.; Milly, P. Estimated accuracies of regional water storage variations inferred from the Gravity Recovery and Climate Experiment (GRACE). Water Resour. Res. 2003, 39, doi:10.1029/2002WR001808.

35. MWI Ministry of Water and Irrigation Web Site, Jordan Water Sector Facts and Figures 2013. 2014. Available online: http://www.mwi.gov.jo/sites/en-us/Documents/W.\%20in\%20Fig.E\% 20FINAL\%20E.pdf (accessed on 6 August 2015).

36. Amelung, F.; Galloway, D.L.; Bell, J.W.; Zebker, H.A.; Laczniak, R.J. Sensing the ups and downs of Las Vegas: In SAR reveals structural control of land subsidence and aquifer-system deformation. Geology 1999, 27, 483-486.

37. Abidin, H.Z.; Andreas, H.; Gamal, M.; Wirakusumah, A.D.; Darmawan, D.; Deguchi, T.; Maruyama, Y. Land subsidence characteristics of the Bandung Basin, Indonesia, as estimated from GPS and InSAR. J. Appl. Geod. 2008, 2, 167-177.

(C) 2015 by the authors; licensee MDPI, Basel, Switzerland. This article is an open access article distributed under the terms and conditions of the Creative Commons Attribution license (http://creativecommons.org/licenses/by/4.0/). 